\title{
PAHLAWAN DAN PECUNDANG: MILITER DALAM NOVEL-NOVEL INDONESIA
}

\author{
Christopher Woodrich \\ Chief Administrative Coordinator International Indonesia Forum \\ Email: chris_woodrich@hotmail.com
}

Judul: Pahlawan dan Pecundang: Militer dalam Novel-Novel Indonesia |

Pengarang: Aprinus Salam dan Ramadya Akmal | Penerbit: Gadjah Mada University Press |

Tahun terbit: 2014 | Jumlah halaman: 136 HALAMAN

$\mathrm{N}$ egara Indonesia lahir dari perang, revolusi melawan kolonialisme Belanda yang dibantu oleh beberapa negara Eropa lain. Setelah itu, pihak militer main peran yang sangat besar dalam menentukan nasib republik ini, lebih-lebih setelah kudeta yang diusahakan Gerakan 30 September serta munculnya Orde Baru, dengan Jenderal Soeharto sebagai presiden. Kaum militer menjadi pengusaha dan menteri; mereka bahkan bertanggung jawab atas agama dan seni. Meskipun dampak sedemikian rupa sudah berkurang, kenyataannya militer masih memiliki kekuasaan yang cukup besar, dan berperan dalam menentukan nasib NKRI ke depan.

Mengingat peran besar militer tersebut, tidak mengherankan kalau banyak karya sastra Indonesia membahas hal-hal yang berkaitan dengan kemiliteran, baik militer kolonial (prakemerdekaan) maupun militer nasional. Militer merupakan dunia yang terpisah dari dunia sipil para sastrawan, tetapi juga bertindak sebagai kekuasaan yang tidak dapat dihindari oleh para penulis. Ia dibanggakan, tapi ditakuti, membela dan dibela, tetapi mencelah dan dicelah. Namun, selama ini hanya sedikit penelitian yang dilakukan terhadap dunia militer dalam karya sastra Indonesia.

Dalam Pablawan dan Pecundang: Militer dalam Novel-Novel Indonesia, Aprinus Salam dan
Ramayda Akmal berusaha untuk menempatkan hubungan sastrawan dan militer dalam era Reformasi (sebagaimana direpresentasikan dalam karya sastra) dalam konteks sosiohistorisnya. Setelah menguraikan hubungan militer dan sipil secara umum, yang menjadi salah satu pedoman kajian ini, mereka membahas hubungan militer dan sastrawan secara historis. Pembahasan ini dibagi menurut periode: masa penjajahan Belanda, masa pendudukan Jepang, masa Orde Lama, masa Orde Baru, dan masa Reformasi.

Menurut hasil penelitian ini, pada masa penjajahan penulis Indonesia mencitrakan militer Belanda sebagai manusia idaman: yang kuat, baik, alim, dan berani. Dalam masa pendudukan Jepang, pihak kolonial Belanda dibuang dan dicitrakan sebagai musuh; yang kuat, baik, alim, dan berani, yang patut dicontohkan, adalah militer Belanda. Dalam Orde Lama, militer adalah orang Indonesia, yang berjuang demi Indonesia; mereka adalah orang yang humanis, patriotis, dan nasionalis, yang menjadi pahlawan bagi bangsanya sendiri. Di Orde Baru, militer terus dianggap sebagai orang yang unggul, yang luar biasa hebat; orang biasa, tokoh utama, tidak bisa sehebat mereka. Dalam keempat periode ini, militer adalah pihak yang layak ditiru, pekerjaan yang layak dicita-citakan, yang melawan musuh negaranya 
(meskipun negara itu berbeda dalam periode yang berbeda) tanpa mengenal lelah. Ia bagaikan superhero, pahlawan yang tak terkalahkan.

Pencitraan itu sudah berubah sama sekali, sebagaimana dijelaskan dalam bagian pokok penelitian ini. Sebagaimana dijelaskan buku ini, wacana yang selama ini menjadi marginalizeddiscourses dimunculkan secara terbuka, dengan menggambarkan militer Orde Baru - bukan militer Reformasi. Menurut novel yang terbit selama masa Reformasi, militer bukanlah pahlawan atau manusia yang unggul. Mereka adalah orang yang keras, yang melakukan kekerasan dan menggunakan kekuasaan mereka dengan sewenang-wenangnya. Militer adalah pihak yang sangat terstruktur, tetapi juga berkasta, di mana pihak yang paling berpangkat juga memiliki kekuasaan yang paling absolut. Mereka bukan melawan musuh negara, apalagi musuh dari luar negara, tetapi masyarakat sipil sendiri - masyarakat yang memberi mandat kepada pemerintah dan, dengan demikian, militer.

Jelaslah,pemetaan dan penelitian ini sangat berguna.Sayangnya, penelitian ini cukup kurang dalam pembahasan militer dalam sastra Indonesia sebelum Reformasi. Biarpun kedua peneliti menegaskan bahwa tujuan utama mereka ialah untuk mengungkap citra militer dalam sastra pasca-Orde Baru, dengan sejarah pencitraan militer dalam kesastraan Indonesia hanya dihadirkan sebagai konteks dari hal tersebut, terasa sekali bahwa sampel yang digunakan untuk menarik kesimpulan ini kurang representatif; hanya tiga novel digunakan untuk merepresentasikan setiap angkutan. Hal ini terjadi karena penelusuran karya-karya sebelumnya dilakukan bukan dengan membaca pelbagai karya, baik yang memuat maupun tidak memuat wacana militer, tapi mencari novel-novel yang memuat wacana militer dalam duabuku yang sudah ada, yaitu Ringkasan dan Ulasan Novel Indonesia Modern dan Perkembangan Novel-Novel Indonesia(hal. 13). Akibatnya, karya yang mungkin dipilih sudah dibatasi oleh seleksi yang sudah dilakukan oleh pengarang kedua buku di atas.
Hal ini paling menonjol ketika kita mempertimbangkan jenis novel yang dibahas. Tanpa perkecualian, novel yang diangkat dalam bab-bab yang membahas sejarah representasi militer dalam sastra Indonesia adalah novel yang dianggap kanon, dari Sitti Nurbaya hingga Ronggeng Dukub Paruk. Sastra di luar kanon diakui dalam suatu catatan kaki singkat pada halaman dua, lalu diabaikan sama sekali. Tidak ada, misalnya, pembahasan kepolisian kolonial (yang, dalam pembahasan Sengsara Membawa Nikmat, disetarakan dengan militer [hal. 44]) sebagaimana direpresentasikan dalam Drama di Boeven Digoel (1938; diserialkan 1929-32) karya Kwee Tek Hoay, atau posisi para jenderal dalam novel popular seperti Ranjau-Ranjau Cinta (1983) karya Marga T.

Kalau novel yang non-kanon seperti ini (atau, dalam istilah kajian wacana, marginalized discourses) dibahas, sudah barang tentu hasil penelitian akan cukup berbeda. Dalam Drama di Boeven Digoel, misalnya, pihak polisi bukan hanya tidak mampu menangkap semua komunis yang melakukan pemberontakan (dalam novel ini, Radeko, yang akhirnya menyerahkan diri), tetapi juga menangkap orang yang salah (Nurani, yang didiuga Subaidah), dimanipulasi oleh pihak sipil (Mustari, Subaidah, dan Radeko, yang kesemuanya sengaja ditangkap supaya mereka bisa bertemu dengan Nurani), dan tidak dapat menghentikan tahanan yang melarikan diri (Mustari, Subaidah, Nurani, dan Radeko, yang kesemuanya dapat melarikan diri ke hutan). Polisi - dan, dengan demikian, militer - bukanlah "pahlawan" ataupun "citacita”. Dalam novel ini, setidaknya, mereka bagaikan badut bersenjata: yang mungkin kadangkala menakutkan, tetapi pada akhirnya tidak bekerja dengan efektif.

Karya Marga T. yang disinggung di atas pun menawarkan suatu wacana (meskipun amat singkat) yang menunjukkan bahwa resistensi terhadap rezim militer Orde Baru tidak semuanya tersembunyi dalam peristiwa masa lampau atau suara pihak "musuh" yang akhirnya terkalahkan. Pada akhir novel, ketika tokoh Mianti akan menikah dengan Budi (dan 
bukan Yos, yang sudah dijodohkan dengan dia oleh orang tuanya), Budi ditangkap polisi karena melakukan aborsi yang membunuh anaknya seorang pejabat - "mungkin jendral" - meskipun ada implikasi bahwa aborsi tersebut dituntut oleh jenderal. Karena yang meninggal itu anak jenderal, "Budi sudah boleh dianggap almarhum saja" (T., 2004: 169).Akhirnya Yos-lah yang menikah dengan Mianti; tidak disebut apabila jenderal itu kena hukum atau tidak. Meskipun peristiwa ini hanya perlu beberapa baris, ia sangat signifikan dalam alur novel Ranjau-Ranjau Cinta, dan juga menunjukkan adanya suatu rasa ketidakpuasan dengan rezim militer Orde Baru, yang dinilai berlaku semena-mena dan sangat kasar dengan masyarakat sipil.Dari dua contoh di atas, nampak kalau pencitraan militer bukanlah sesuatu yang monolitik, tetapi beragam.

Biarpun ada kekurangan ini, penelitian yang dihasilkan Aprinus dan Ramayda ini sangat berharga, dan dapat dijadikan titik mula untuk penelitian-penelitian serupa dalam bidang lain, atau sebagai perbandingan untuk penelitian nilai militer dalam periode tertentu. Karyakarya yang berkaitan dengan militer tentu tidak hanya terbatas pada novel yang adiluhung, tetapi juga ditemukan dalam sastra populer, novel anak, cerita pendek, dan bahkan puisi. Sangat layak untuk kita membandingkan sifatsifat militer yang terepresentasi dalam mediamedia tersebut dengan yang ditemukan dalam novel, karena masih mungkin ada wacana yang termarjinalkan yang dihadirkan melalui satu bentuk media dan bukan yang lain.

Penelitian selanjutnya dalam bidang novel juga akan bermanfaat, mengingat booming-nya novel-novel yang berkaitan dengan peperangan pada masa kerajaan. Buku-buku ini belum disinggung oleh Aprinus Salam dan Ramadya Akmal, sebab para pejuang ini (Gajah Mada, misalnya) tidak berjuang demi suatu negara (country), melainkan suatu negeri (kingdom). Akan tetapi, ia masih termasuk bagian dari sejarah peperangan, sehingga mungkin dapat dianggap "pra-militer" atau "proto-militer". Apabila ditelusuri secara lebih mendalam, fenomena ini mungkin dapat menjelaskan apakah fenomena mutakhir ini merupakan usaha untuk mengangkat kembali nama baik militer Indonesia yang sudah tidak dipercaya oleh rakyat, dan menciptakan citra positif untuk mereka, dengan mengalihkan bentuknya menjadi bentuk yang masih sering dipuji. Bisa terjadi, wacana militer dalam sastra Indonesia terus berkembang.

\section{Daftar Pustaka}

Hoay, Kwee Tek. 2001. (1938). Drama di Boven Digoel. Dalam Kesastraan Melayu Tionghoa dan Kebangsaan Indonesia, jilid 3.Kepustakaan Popular Gramedia: Jakarta.

Salam, Aprinus dan Ramadya Akmal. 2014. Pablawan dan Pecundang: Militer dalam Novel-Novel Indonesia. Gadjah Mada University Press: Yogyakarta

T., Marga. 2004. (1983). Ranjau-Ranjau Cinta. Gramedia: Jakarta. 